\title{
Chapter 4 \\ Article 6: The Rights to Life, Survival, and Development
}

\section{Ziba Vaghri}

1. States Parties recognise that every child has the inherent right to life.

2. States Parties shall ensure to the maximum extent possible the survival and development of the child.

\section{What Did Children Say?}

'A minimum income for every family with children should be secured by the government and reports should be available about its provision.' (Eastern Europe)

'Children must have a health insurance for making sure that they will grow up without health challenges make their growth difficult.' (Asia-Pacific)

'All government departments should do everything they can to ensure the survival and development of children. For example, government should set up more schools so that we children have opportunities to continue their schoolwork.' (Asia-Pacific)

\footnotetext{
Z. Vaghri $(\bowtie)$

University of New Brunswick Saint John, Saint John, NB, Canada

e-mail: ziba.vaghri@unb.ca 


\section{Overview}

Article 6 guarantees the child's inherent right to life, and, for the first time in an international human rights treaty, introduces the right to survival and development. ${ }^{1}$ The right to life is the only right defined as inherent in the Convention. It extends beyond a negative obligation of non-interference, imposing a proactive obligation to take all comprehensive legislative, administrative, and other positive measures to ensure the inherent and indivisible right to life and survival of the child (Nowak, 2005, pp. 17-18). Although the right to life is not absolute, the standard to justify any failure to protect the life of a child is exceptionally high (Peleg \& Tobin, 2019). States Parties are required to provide explicit protections in law which include strict circumscribing of measures that arbitrarily and non-arbitrarily deprive a child's life (Nowak, 2005, p. 2). Consistent with Article 37, Article 6 must be interpreted as imposing a prohibition on the death penalty (UN Committee on the Rights of the Child, 2010, paras. 32-33, 2012a, paras. 37-38). In addition, in line with Article 1 , which avoids taking a position on the commencement of life, Article 6 does not adopt a view with regard to whether life begins at the point of conception or a live birth. States Parties are therefore able to determine this issue themselves (Peleg \& Tobin, 2019; UN Committee on the Rights of the Child, 2005a, para. 64 (c)). The Working Group drafting the Convention noted that staying silent on such matters was intentional so as 'not to prejudice the interpretation of Article 1 or any other provisions of the Convention by State Parties' (UN Commission on Human Rights, 1989, pp. 8-15).

Paragraph 2 of Article 6 introduces the obligation on States Parties to ensure the survival and development of the child to the maximum extent possible. ${ }^{2}$ The development of the child has been interpreted by the Committee as needing to be understood 'in its broadest sense as a holistic concept embracing the child's physical, mental, spiritual moral and psychological development' (2003, para. 12, 2013a, para. 18). It imposes an obligation on States Parties to introduce all appropriate measures, both positive and negative, to promote the survival and development of the child. Its implementation is integrally linked to the Convention in its entirety, and in particular the principle of the best interests of the child in Article 3 , as well as the rights to health and an adequate standard of living and education in Articles 24, 27,

\footnotetext{
${ }^{1}$ See General Guidelines for Initial Reports (UN Committee on the Rights of the Child, 1991, para. 13), and General Guidelines for Periodic Reports (UN Committee on the Rights of the Child, 1996, para. 40), where it defined Article 6: 'specific measures taken to guarantee the child's right to life and to create an environment conducive to ensuring to the maximum extent possible the survival and development of the child, including physical, mental, spiritual, moral, psychological and social development, in a manner compatible with human dignity, and to prepare the child for an individual life in a free society.'

${ }^{2}$ As defined in the Convention on the Rights of the Child Article 27, General Comment No. 5 (UN Committee on the Rights of the Child, 2003), a report on implementation in the context of migration (UN Office of the High Commissioner for Human Rights (OHCHR), 2010), and the Implementation handbook (Hodgkin et al., 2007)
} 
28 and 29 (Nowak, 2005, p. 14). General Comment no. 7 illustrates this point by drawing the links to 'health, adequate nutrition, social security and adequate standard of living, a healthy safe environment, education and play, along with the respect for parental responsibility and the provision of assistance and quality services' (UN Committee on the Rights of the Child, 2006, para. 10).

\section{General Principles}

Article 2 Measures such as access to information, services, and supports that promote life and development must be undertaken to prevent discrimination of children, including those with disabilities and survivors of gender-based violence.

Article 3 Innately linked to child's right to life, survival, and development, Article 3 obliges States to "create an environment that respects human dignity and ensures the holistic development of every child. In the assessment and determination of the child's best interests, the State must ensure full respect for his or her inherent right to life, survival and, development' (UN Committee on the Rights of the Child, 2013b, para. 42).

Article 12 The views of children must be listened to and given due weight in all matters that affect their life, survival, and development.

\section{Articles Related or Linked to Article 6}

As a General Principle, Article 3 needs to be considered in relation to the implementation of all the other Convention rights. However, rights that require specific consideration of the child's right to life and optimum survival and development include those below.

Article 19, protection from all forms of violence that are detrimental to the child's life and development.

Article 32 offers protections from economic exploitation and hazardous work.

Article 33 protects children from the use of illicit narcotics and psychotropic substances, as well as being protected from involvement in the trade, production, and trafficking of illicit drugs.

Article 34 protects from sexual exploitation and abuse, including inducement and coercion to engage in unlawful activity, exploitation through prostitution and other unlawful practices as well as exploitative use in pornographic materials and production.

Article 35, protections to prevent abduction, sale, or trafficking of children for any purpose or in any form.

Article 36 protects from all other forms of exploitation prejudicial to any aspect of a child's welfare. 
Article 37(a) prohibits torture and cruel, inhumane, and degrading treatment and punishment. Securing the right to life is therefore conceived as right to personal liberty and security. This includes the prohibition of capital punishment of children. Article 6 of both the Convention and the ICCPR reinforce the abolishment of the death penalty for children. It is not enough to not apply the death penalty, but rather legislation must be explicit in the prohibition of its use. Children's optimum development must also be protected from the potential harm that might be imposed by excessive use of force by law enforcement or others in power.

Article 38 relates to the protection of the child in armed conflict. The risk to life is considerable for the child in these circumstances. Apart from the risk of death, children living in a conflict zone can be vulnerable to displacement, recruitment, malnutrition, poor health and sanitation, and related illnesses. These children are also at potential risk of torture, disappearance, extrajudicial killings and social cleansing (UN Committee on the Rights of the Child, 2000a, paras. 30-31, 2000b, paras. 34-35). In zones of conflict, landmines have been responsible for the deaths of children and other members of the community. Importantly, ICCPR declares there is no derogation permitted even in times of emergency (United Nations, 2006, p. 166).

\section{Relevant Instruments}

The UN Universal Declaration of Human Rights (1948), Article 3, affirms 'the right to life, liberty, and security of person.'

The International Covenant on Civil and Political Rights (1966), Article 6, while asserting the right to life, declares it be protected by law and that a person must not be arbitrarily deprived of life (United Nations, 2006, p. 166).

The UN Convention on the Rights of Persons with Disabilities (2006), Article 10, asserts States Parties affirm the inherent right to life, and the employment of all measures to ensure people with disabilities the enjoyment of that right on the equal basis as other persons. This would include equal access to systems of health and care available to other members of society. Children with disabilities, particularly infants, are highlighted as being vulnerable to exclusion or discrimination as a result of impoverished systems of care and limited access to health. States Parties are urged to outlaw harmful practices that impinge on the right to life of children with disabilities. States Parties are also required to raise public awareness, enact legislation, and review and revise laws that directly or indirectly violate the right to life, survival, and development of children with disabilities (UN Committee on the Rights of the Child, 2007, para. 31). 


\section{Attributes}

\section{Attribute One: Respect for and Protection of Inherent Right to Life of the Child}

The right to life has been referred to as 'the supreme right,' as without it all other human rights would be devoid of meaning (UN Human Rights Committee, 2019, paras. 2-3). Furthermore, its recognition by the Committee as a General Principle affirms the imperative to take it into account in the implementation of all other rights (Doek, 2015).

Unlike other human rights treaties, the States Parties' obligation for the respect for inherent right to life in Article 6 does not come with a limitation clause of arbitrary deprivation of life. It therefore prohibits any act that is detrimental to the child's inherent dignity and right to life, including death penalty, corporal punishment, torture or other cruel, inhuman, or degrading treatment or punishment (Nowak, 2005, pp. 18-24). The Committee has argued that the right to life requires more than refraining from imposition of the death penalty, and places positive obligations to prohibit children from receiving life sentences. The right to life means more than simply being alive-the quality of life is as relevant as its preservation (UN Committee on the Rights of the Child, 2011a, para. 38).

Likewise, obligations to protect the child's inherent right to life go beyond traditional understanding of the state protecting the child from undue interference of right to life by the state itself or private parties. It requires States Parties to set up comprehensive legislative measures, including in the fields of criminal law, family law, and police and labour law, as well as due diligence through effective implementation and enforcement of these laws (Nowak, 2005, pp. 24-36). For example, action is needed to protect children from loss of life, investigate and prosecute where necessary in cases of loss of life, and provide compensation and reparation as appropriate (Peleg \& Tobin, 2019). Furthermore, the right to life is inextricably linked to the right to survival, requiring measures to increase life expectancy as well as those that protect against and mitigate the consequences of climate change, including, for example ${ }^{3}$ :

- Lowering preventable causes of death and infant mortality

- Promoting universal sanitation

- Accessibility to clean water and pre-natal care

- Eliminating malnutrition and epidemics

- Increasing safety to reduce traffic and other forms of accident such as drowning.

Measures to protect children from violence are fundamental to the preservation of the right to life. The Committee has identified, for example, gang-related violence

\footnotetext{
${ }^{3}$ See, for example: Concluding Observations: Portugal (2014a, para. 29), Concluding Observations: Mozambique (2009a, paras. 33-34), the Implementation Handbook (Hodgkin et al., 2007, p. 84), and the declaration of the World Summit for Children (World Summit for Children, 1990).
} 
and the vulnerability of children in street situations to violent threats to life as violations of Article 6, and called on States Parties to adopt a coordinated and structured approach to addressing these issues and ensuring the right to life of these children (2014b, paras. 3-5). ${ }^{4}$ In line with Article 2, the Committee has also called attention to the obligation of States Parties to undertake measures that address discriminatory harmful practices that can threaten the right to life, including genderbased violence, forced marriages, gender selection, matters related to affected LGBTQ and intersex children, early marriage, 'honour killings,' and ritualistic killing of children with albinism, those accused of witchcraft, or children with disabilities (2007, para. 31, 2013c, para. 28).

In addition, the Committee has highlighted concerns over the issue of child suicide, particularly among those held in detention, and urged States Parties to take measures that address factors that render children vulnerable to suicide and self-harm, and to seek to minimise all possible risk (Peleg \& Tobin, 2019). Finally, the Committee has expressed repeated concern over the impact of armed conflict on the child's right to life. ${ }^{5}$ Protection of the right to life in these contexts is complex and requires an understanding of the interface between international humanitarian law and human rights law (addressed more fully under Article 38). However, it has urged States Parties to strengthen protection of children in respect of conflicts in which the state itself and non-state actors are responsible for breaching the right to life. $^{6}$

\section{Attribute Two: Ensuring the Development and the Survival of the Child to the Maximum Extent Possible}

The inclusion of the obligation to ensure to the maximum extent possible the survival and development of the child reflects a commitment to translate into international human rights law the provisions in the 1959 Declaration of the Rights of the Child to provide special protection and 'to grow and develop in health.' Thus, paragraph 2 of Article 6 needs to be understood as providing the umbrella protection for survival and development of the child.

The obligations to ensure the survival of the child are elaborated in multiple articles in the Convention, including (Nowak, 2005, pp. 43-48):

\footnotetext{
${ }^{4}$ See, for example, concluding observations for Venezuela (2014b, para. 32) and Jamaica (2015, paras. 24-25).

${ }^{5}$ See, for example, concluding observations for Iraq (2000c, para. 23) and the Philippines (1995, para. 32).

${ }^{6}$ See, for example, concluding observations for Israel (2013d, paras. 25-26) and the Democratic Republic of Congo (2009b, para. 33).
} 
- The right to health and adequate nutrition (Article 24)

- The right to an adequate standard of living, eradication of poverty and provision of basic material needs (Article 27)

- The right to recovery and rehabilitation (Articles 19 and 39)

- The right to preventive measures from harm such as provisions of information to children and parent for optimal development of the child (Articles 24, 5, 12, 17)

- Protection from exploitation and abuse in general and in times of forced displacement by natural and/or man-made causes. (Articles 19, 32-36).

In general, the factors most critical to a child's survival are more appropriately dealt with under the relevant articles. However, the Committee has used Article 6 to highlight a range of issues related to the survival of children, including acute respiratory infections and diarrhoea, anaemia, measles, pneumonia, HIV/AIDS, poor pre- and post-natal care, and low immunisation rates. ${ }^{7}$

The right to development must be understood in terms of the personal development of the child, rather than wider collective social and economic development. The concept is referenced throughout the Convention, including:

- Education including development of the child's talents, personality, respect for human rights, environment (Articles 28-29)

- Supportive measures to parents so that they can provide the best possible parenting (Articles 18 and 27 para 3) (UN Committee on the Rights of the Child, 2016, para. 50; UN Human Rights Council, 2016)

- Provision for children with disabilities including cultural and spiritual development (Article 23)

- An adequate standard of living for children's physical, mental, spiritual, moral and social development (Article 27)

- Protection for children against work that is harmful to their health or physical, mental, spiritual moral or social development.

The breadth of the implications of the right to survival and development can therefore be seen to provide a clear underpinning for the Committee's decision to identify Article 6 as a General Principle. Although most of the Committee's relevant recommendations could be applied to other specific rights, it has nevertheless used Article 6 to press States Parties to undertake all appropriate legislative, administrative, social, and educational measures to ensure the survival and development of the child, including:

- The needs of children in street situations (2017, paras. 31-32)

- Household food insecurity (2008a, para. 30)

- Access to sanitation (2008b, para. 30)

- Outreach of health, nutrition and birth registration services (2011b, para. 35(b))

\footnotetext{
${ }^{7}$ See, for example, concluding observations for Nepal (2005b, para. 60) and Côte d'Ivoire (2001, para. 38).
} 
- Access to early years care (2004, para. 35)

- Support for pregnant adolescents (2012b, para. 32).

However, while the text in paragraph 2 demands that States Parties 'ensure' the survival and development of the child, the consequent obligations are qualified by the phrase 'to the maximum extent possible.' The factors that can be used to justify limitations on efforts on the part of the state include availability of resources, and acts or omission by parents, other actors, or the child themself (Peleg \& Tobin, 2019).

\section{References}

Doek, J. E. (2015). Article 6 CRC and the views of the CRC Committee. Stellenbosch Law Review, 26(2), 254-271.

Hodgkin, R., Newell, P., \& UNICEF. (2007). Implementation handbook for the Convention on the Rights of the Child (3rd ed.). UNICEF. Accessed September 21, 2020, from https:// digitallibrary.un.org/record/620060? $1 \mathrm{n}=\mathrm{en}$

Nowak, M. (2005). A commentary on the United Nations Convention on the Rights of the Child, Article 6: The right to life, survival and development. Brill Nijhoff. Accessed September 22, 2020, from https://brill.com/view/title/11606.

Peleg, N., \& Tobin, J. (2019). Article 6: The rights to life, survival and development. In J. Tobin (Ed.), The UN Convention on the Rights of the Child: A commentary (pp. 186-236). Oxford University Press.

UN Commission on Human Rights. (1989). Report of the Working Group on a Draft Convention on the Rights of the Child, 1989, E/CN.4/1989/48. Accessed October 12, 2020, from https:// digitallibrary.un.org/record/57437? $1 \mathrm{n}=\mathrm{en}$.

UN Committee on the Rights of the Child. (1991, October 30). General guidelines regarding the form and content of initial reports to be submitted by States Parties under article 44, paragraph 1(a), of the Convention, CRC/C/5. Accessed October 12, 2020, from https://digitallibrary.un. org/record/137523? In=en.

UN Committee on the Rights of the Child. (1995, June 20). Concluding observations: Nicaragua, CRC/C/15/Add.36. Accessed October 11, 2020, from https://digitallibrary.un.org/record/ $191818 ? \ln =\mathrm{en}$.

UN Committee on the Rights of the Child. (1996, November 20). General guidelines regarding the form and contents of periodic reports to be submitted by states parties under article 44, paragraph 1 (b) of the Convention, CRC/C/58. Accessed October 12, 2020, from https:// digitallibrary.un.org/record/230051? $1 \mathrm{n}=\mathrm{en}$.

UN Committee on the Rights of the Child. (2000a, October 16). Concluding observations: Burundi, CRC/C/15/Add.133. Accessed October 11, 2020, from https://digitallibrary.un.org/record/ $429241 ? \ln =$ en.

UN Committee on the Rights of the Child. (2000b, October 16). Concluding observations: Colombia, CRC/C/15/Add.137. Accessed October 11, 2020, from https://digitallibrary.un.org/ record $/ 429246 ? \ln =$ en.

UN Committee on the Rights of the Child. (2000c, June 28). Concluding observations: Iran, CRC/C/15/Add.123. Accessed October 12 2020, from https://digitallibrary.un.org/record/ $422916 ? \ln =$ en.

UN Committee on the Rights of the Child. (2001, July 9). Concluding observations: Côte d'Ivoire, CRC/C/15/Add.155. https://digitallibrary.un.org/record/451939?ln=en 
UN Committee on the Rights of the Child. (2003, November 27). General comment no. 5 (2003) General measures of implementation of the Convention on the Rights of the Child (arts. 4, 42 and 44, para. 6), $C R C / G C / 2003 / 5$. Accessed October 12, 2020, from https://digitallibrary.un. org/record $/ 513415 ? \ln =$ en.

UN Committee on the Rights of the Child. (2004, February 26). Concluding observations: Slovenia, CRC/C/15/Add.230. Accessed October 12, 2020, from https://digitallibrary.un.org/record/ $530811 ? \mathrm{ln}=\mathrm{en}$.

UN Committee on the Rights of the Child. (2005a, September 21). Concluding observations: Costa Rica, CRC/C/15/Add.266. Accessed October 11, 2020, from https://digitallibrary.un.org/record/ $570468 ? \ln =\mathrm{en}$.

UN Committee on the Rights of the Child. (2005b, September 1). Concluding observations: Nepal, CRC/C/15/Add.261. Accessed October 11, 2020, https://digitallibrary.un.org/record/569886? $\ln =$ en.

UN Committee on the Rights of the Child. (2006, September 20). General comment no. 7 (2005) Implementing child rights in early childhood, CRC/C/GC/7/Rev.1. Accessed October 12, 2020, from https://digitallibrary.un.org/record/584854? ln=en.

UN Committee on the Rights of the Child. (2007, November 13). General comment no. 9 (2006) The rights of children with disabilities, $C R C / C / G C / 9$. Accessed October 12, 2020, from https:// digitallibrary.un.org/record/593891? $\mathrm{ln}=\mathrm{en}$.

UN Committee on the Rights of the Child. (2008a, June 20). Concluding observations: Sierra Leone, CRC/C/SLE/CO/2. Accessed October 12, 2020, from https://digitallibrary.un.org/record/ $630782 ? \ln =\mathrm{en}$.

UN Committee on the Rights of the Child. (2008b, October 7). Concluding observations: Djibouti, $C R C / C / D J I / C O / 2$. Accessed October 12, 2020, from https://digitallibrary.un.org/record/ $639146 ? \ln =\mathrm{en}$.

UN Committee on the Rights of the Child. (2009a, November 4). Concluding observations: Mozambique, CRC/C/MOZ/CO/2. Accessed October 11, 2020, from https://digitallibrary.un. org/record/671008? $\ln =$ en.

UN Committee on the Rights of the Child. (2009b, February 10). Concluding observations: Democratic Republic of the Congo, CRC/C/COD/CO/2. Accessed October 12, 2020, from https://digitallibrary.un.org/record/648538? $\mathrm{ln}=\mathrm{en}$.

UN Committee on the Rights of the Child. (2010, June 21). Concluding observations: Nigeria, CRC/C/NGA/CO/3-4. Accessed October 11, 2020, from https://digitallibrary.un.org/record/ $685180 ? \ln =\mathrm{en}$.

UN Committee on the Rights of the Child. (2011a, July 15). Concluding observations: Egypt, $C R C / C / E G Y / C O / 3-4$. Accessed October 11, 2020, from https://digitallibrary.un.org/record/ $707466 ? \mathrm{ln}=\mathrm{en}$.

UN Committee on the Rights of the Child. (2011b, August 3). Concluding observations: Bahrain, $C R C / C / B H R / C O / 2-3$. https://digitallibrary.un.org/record/708488? $\mathrm{ln}=\mathrm{en}$

UN Committee on the Rights of the Child. (2012a, December 13). Concluding observations: Liberia, $C R C / C / L B R / C O / 2-4$. Accessed October 11, 2020, from https://digitallibrary.un.org/ record/739973? $\mathrm{ln}=\mathrm{en}$.

UN Committee on the Rights of the Child. (2012b, October 16). Concluding observations: Namibia, CRC/C/NAM/CO/2-3. Accessed October 12, 2020, from https://digitallibrary.un.org/ record/736633? ln=en.

UN Committee on the Rights of the Child. (2013a, April 17). General comment no. 16 (2013) on State obligations regarding the impact of the business sector on children's rights, $C R C / C / G C /$ 16. Accessed October 12, 2020, from https://digitallibrary.un.org/record/778525? $1 \mathrm{n}=$ en.

UN Committee on the Rights of the Child. (2013b, May 29). General comment no. 14 (2013) On the right of the child to have his or her best interests taken as a primary consideration (art. 3, para. 1), $C R C / C / G C / 14$. Accessed October 12, 2020, from https://digitallibrary.un.org/record/ $778523 ? \mathrm{ln}=\mathrm{en}$. 
UN Committee on the Rights of the Child. (2013c, July 8). Concluding observations: GuineaBissau, CRC/C/GNB/CO/2-4. Accessed October 12, 2020, from https://digitallibrary.un.org/ record/756269? $1 \mathrm{n}=$ en.

UN Committee on the Rights of the Child. (2013d, July 4). Concluding observations: Israel, $C R C / C / I S R / C O / 2-4$. Accessed October 12, 2020, from https://digitallibrary.un.org/record/ $756274 ? \ln =$ en.

UN Committee on the Rights of the Child. (2014a, February 25). Concluding observations: Portugal, CRC/C/PRT/CO/3-4. Accessed October 11, 2020, from https://digitallibrary.un.org/ record $/ 778846 ? \mathrm{ln}=\mathrm{en}$.

UN Committee on the Rights of the Child. (2014b, October 13). Concluding observations: Venezuela, CRC/C/VEN/CO/3-5. Accessed October 12, 2020, from https://digitallibrary.un. org/record/785293? ln =en.

UN Committee on the Rights of the Child. (2015, March 10). Concluding observations: Jamaica, $C R C / C / J A M / C O / 3-4$. Accessed October 12, 2020, from https://digitallibrary.un.org/record/ $789759 ? \mathrm{ln}=\mathrm{en}$.

UN Committee on the Rights of the Child. (2016, December 6). General comment no. 20 (2016) on the implementation of the rights of the child during adolescence, $C R C / C / G C / 20$. Accessed October 12, 2020, from https://digitallibrary.un.org/record/855544? $\mathrm{ln}=\mathrm{en}$.

UN Committee on the Rights of the Child. (2017, June 21). General comment no. 21 (2017) on children in street situations, CRC/C/GC/21. Accessed October 12, 2020, from https:// digitallibrary.un.org/record/1304490? $\mathrm{ln}=\mathrm{en}$.

UN Human Rights Committee. (2019, September 3). CCPR general comment no. 36 (2019) Article 6, Right to life, $C C P R / C / G C / 36$. https://digitallibrary.un.org/record/3884724? $1 \mathrm{n}=\mathrm{en}$

UN Human Rights Council. (2016). Report of the Special Rapporteur on the right of everyone to the enjoyment of the highest attainable standard of physical and mental health A/HRC/32/32. http:// digitallibrary.un.org/record/842322

United Nations. (2006). Compilation of general comments and general recommendations adopted by human rights treaty bodies, HRI/GEN/1/Rev. 8. UN. Accessed April 19, 2020, from http:// digitallibrary.un.org/record/576098.

UN Office of the High Commissioner for Human Rights (OHCHR). (2010). Report of the Office of the United Nations High Commissioner for Human Rights on challenges and best practices in the implementation of the international framework for the protection of the rights of the child in the context of migration, 2010, A/HRC/15/29. https://documents-dds-ny.un.org/doc/UNDOC/ GEN/G10/151/41/pdf/G1015141.pdf?OpenElement

World Summit for Children. (1990). World declaration on survival, protection and development of children. https://ec.europa.eu/anti-trafficking/sites/antitrafficking/files/world_declaration_on_ children_1990_en_1.pdf

Open Access This chapter is licensed under the terms of the Creative Commons Attribution 4.0 International License (http://creativecommons.org/licenses/by/4.0/), which permits use, sharing, adaptation, distribution and reproduction in any medium or format, as long as you give appropriate credit to the original author(s) and the source, provide a link to the Creative Commons license and indicate if changes were made.

The images or other third party material in this chapter are included in the chapter's Creative Commons license, unless indicated otherwise in a credit line to the material. If material is not included in the chapter's Creative Commons license and your intended use is not permitted by statutory regulation or exceeds the permitted use, you will need to obtain permission directly from the copyright holder.

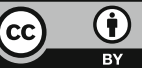

